\title{
Relationship of Revenue, Expenditure, Capital, Grand, and Tax's with Financial Performance of Nangroe Aceh Darussalam Province
}

\author{
Luluk Latifah ${ }^{1}$, Puji Handayati ${ }^{2}$, Iskandar Ritonga ${ }^{3}$, Lutfi Agus Salim ${ }^{4}$, Ahmad Zahro $^{5}$, Fatmah $^{6}$, \\ Akhmad Ali Arifin ${ }^{7}$ \\ ${ }^{1}$ Doctoral Student in Islamic University State of Sunan Ampel, Surabaya, Indonesia \\ ${ }^{2}$ Doctor in Accounting, Faculty of Economics, UNM Malang, Indonesia \\ ${ }^{3}$ Doctor in Sharia Economics Postgraduate, UINSA, Surabaya, Indonesia \\ ${ }^{4}$ Doctor in Biostatistic, Faculty of Public Health, UNAIR, Surabaya, Indonesia \\ ${ }^{5}$ Professor in Graduate Program, UINSA, Surabaya, Indonesia \\ ${ }^{6,7}$ Doctor in Islamic Economic and Business Faculty, UINSA Surabaya, Indonesia
}

\section{Corresponding Author: Luluk Latifah}

\begin{abstract}
Objective Provincial government is part of the central government which autonomously has its own authority in carrying out its APBD so that it can be utilized as much as possible for the prosperity of the people. Good financial performance of the regional government will make the welfare of the people in the area also better. This research is a literature study on the regional government of the province of Nangroe Aceh Darussalam for ten years 2009-2018.

Method - The type of data used is secondary data, APBD (Regional Budget) reports in the form of audited budget and realization. Financial performance instruments are measured based on effectiveness, efficiency and independence. Data were analyzed using Pearson bivariate correlation analysis.

Results - Research has fulfilled the classical assumption test, and the results of Pearson's bivariate correlation show that revenue, expenditure and taxs have a very close positive relationship with the financial performance of the Aceh government, while capital and grand have a weak relationship.

Implications - The results show that the financial performance of the Nangroe Aceh Darussalam provincial government is quite good. This good condition can be improved to be very good through efforts to focus improvements on the variables that are lacking, namely capital and grand.
\end{abstract}

KEY WORDS: Relationship, Revenue, Expenditure, Capital, Grand, Tax

\section{INTRODUCTION}

Regional financial management is regulated in Law No. 23 of 2014 concerning Regional Government. Law no.23 of 2014 is a renewal of Law no. 22 of 1999, which regulates regional autonomy. One of the regional authorities regulated in regional autonomy is the authority in terms of regional financial management. While the relationship between central finance and regional finance is regulated in Law No.33/2004 concerning the balance between Central Government Finance and Regional Government Finance, this law is a renewal of Law No.25 / 1999.

Aceh is a province with a special legal community unit and is given special authority to regulate and manage its own government affairs and the interests of local communities in accordance with the laws and regulations in the system and principles of the Unitary State of the Republic of Indonesia based on the 1945 Constitution of the Republic of Indonesia.
In Aceh the system is enforced sharia is included in the management and financial reporting. This makes it interesting to study, especially about its financial performance. Many researchers have discussed the financial performance of local governments, but no one has examined the financial performance of sharia regional governments, such as the regional government of Aceh Darussalam.

In measuring the financial performance of local governments, it is necessary to have clear indicators and benchmarks including the use of a concept of financial performance measurement approaches that are expressed in financial ratios and identified from the financial statements of local governments. The purpose of this study was to analyze the financial performance of the government of the Province of Nangroe Aceh Darussalam based on data from 2009 to 2018 financial statements. 


\section{REVIEW OF LITERATURE}

\subsection{Government Financial Reports}

According to Law No. 17/2003 concerning State finance which requires the form and content of the APBN / APBD accountability report. prepared and presented in accordance with accounting standards with the type of financial statements that must be submitted include: (1) Budget Realization Report (2) Balance Sheet (3) Cash Flow Report (4) Notes to Financial Statements.

Information in local government financial statements must have certain qualitative characteristics. There are four characteristics that must be fulfilled by the financial statements presented, the financial statements must be: relevant, reliable, consistency, and comparability which are the normative prerequisites needed for government financial reports to meet the desired quality.

Conceptual Framework for Government Accounting Paragraph 33, if it meets the following criteria: (1) Benefits of feedback (2) Benefits of predictive value. (3) Complete. (4) Timely or information is presented on time so that it can be influential and useful in decision making.

\subsection{Government Performance Reporting and} Measurement

The Government Accounting Standard Board (GASB), in the Concept Statements, divides performance measurements into three categories of indicators, namely (1) service effort measurement indicators, (2) service accomplishment measurement indicators, and (3) indicators that connect effort and achievement. Service efforts means how resources are used to carry out various programs or services that are diverse. Service accomplishment is defined as the achievement of a particular program. In addition, certain explanations relating to this performance reporting (explanatory information) are also needed. These measurements report what services are provided by the government, whether the services have met the specified objectives and whether the effects on the service recipient. Comparison of service efforts with service accomplishment is the basis for assessing the efficiency of government operations (GASB, 1994).

In accordance with Public Sector Accounting Standards Statement No. 1 concerning the Preparation of Government Financial Statements, the government's financial performance is measured using the perspective of efficiency, effectiveness and economics. According to Mardiasmo (2007: 4) efficiency is a comparison of inputs with input values expressed in monetary units. Effectiveness is the ratio of output / input associated with performance standards or targets that have been set.

\section{RESEARCH METHODOLOGY}

\subsection{Research Question}

How is the financial performance of the Provincial Government of Nangroe Aceh Darussalam?

\subsection{Objectives of the study}

This study aims to examine the closeness of the relationship between revenue, expenditure, capital, taxes, and ROE, with the financial performance of the government of the Province of Nangroe Aceh Darussalam expressed in ratios (effectiveness, efficiency and Independence).

\subsection{Hypothesis Development}

3.3.1 $\mathrm{H}_{1}$ : There is relationship between revenue and the financial performance of local governments.

Revenue is local government revenue which is used as a source of development funding in the region. According to Government Accounting Standards, regional income comes from two sources namely: local own-source revenue and revenue from provincial and central government transfers.

According to Mahmudi (2007: 128) the higher the amount of regional income, the greater the funds available for regional development McGowen (1983) also states that revenue has an influence on the government's ability to produce financial performance. Meanwhile. Jones and Walker (2007) state that the amount of local government revenue has a strong influence on the financial strength of local government. The higher the amount of local government revenue, the less likely the regional government will experience financial difficulties in funding infrastructure for the development of the relevant local government. Then the first hypothesis that is built is:

3.3.2 $\mathrm{H}_{2}$ : There is relationship between expenditure and the financial performance of local governments.

Expenditure is the amount of expenditure carried out by local governments in a certain period. Expenditure in government is called shopping. which is classified as operational expenditure and capital expenditure.

According to Halim and Damayanti (2008: 5) the high amount of capital expenditure indicates that local governments are spending more on long-term assets so that the impact on the performance of local governments will be felt in a few years after the capital expenditure took place. McGowen (1983) empirically proved that the amount of expenditure has an effect on government financial performance. The greater the amount of expenditure indicates that the growth of local government development is high so that there are government efforts to meet infrastructure needs in the provision of services to the community. The same thing was conveyed by Mahmudi (2007: 146). Then the second hypothesis that is built is:

\subsubsection{H3: There is relationship between capital and the financial performance of local governments.}

Capital or fund equity is the difference between the amount of assets and the amount of liabilities owned by the regional government. The high amount of fund equity indicates that the regional government has sufficient funds to finance the operational activities of the regional government so that it can achieve high financial performance as well. Conversely, 


\section{Darussalam Province"}

if the regional government has or experiences a lack of equity funds, the regional government will experience a shortage of funds to finance operational activities in order to provide services to the community so that it will obtain suboptimal performance.

Cohen (2006) tested the influence of the amount of capital. Empirical evidence obtained is the influence of the amount of local government equity with local government financial performance, then the third hypothesis is

\subsubsection{H4: There is relationship between Taxs and the} financial performance of local governments.

Taxes are regional tax revenue and provincial and central regional tax revenue sharing. High taxes obtained by a local government can be a source of income for local governments so that it can be used as a source of funding for government operations.

According to Steven and McGowen (1983) the level of tax revenue by a local government affects the financial performance of local governments. Anderson (2004) obtained research results similar to Steven and McGowen
(1983). Anderson's (2004) results indicate that an increase in taxes increases the value of local government property and is related to the amount of local government revenue, hence the fourth hypothesis as follows.

\subsubsection{H5: There is relationship between grand and the financial performance of local governments.}

Grants or gifts, donations, donations are receipts received by local governments from other parties without any demands.

According to Steven and McGowen (1983) grants affect the financial performance of local governments. The higher the number of grants, the higher the financial performance that can be achieved by local governments. Meanwhile, Worthington and Dollery (1999) linked grants to the efficiency and effectiveness of local government financial performance, that government financial performance was positively related to the efficiency and effectiveness of local government financial performance. The higher the number of grants received by local governments the higher the level of efficiency and effectiveness of the financial performance of local governments, the fifth hypothesis is:

\section{Geaph 3.1: Theoritical Framework}

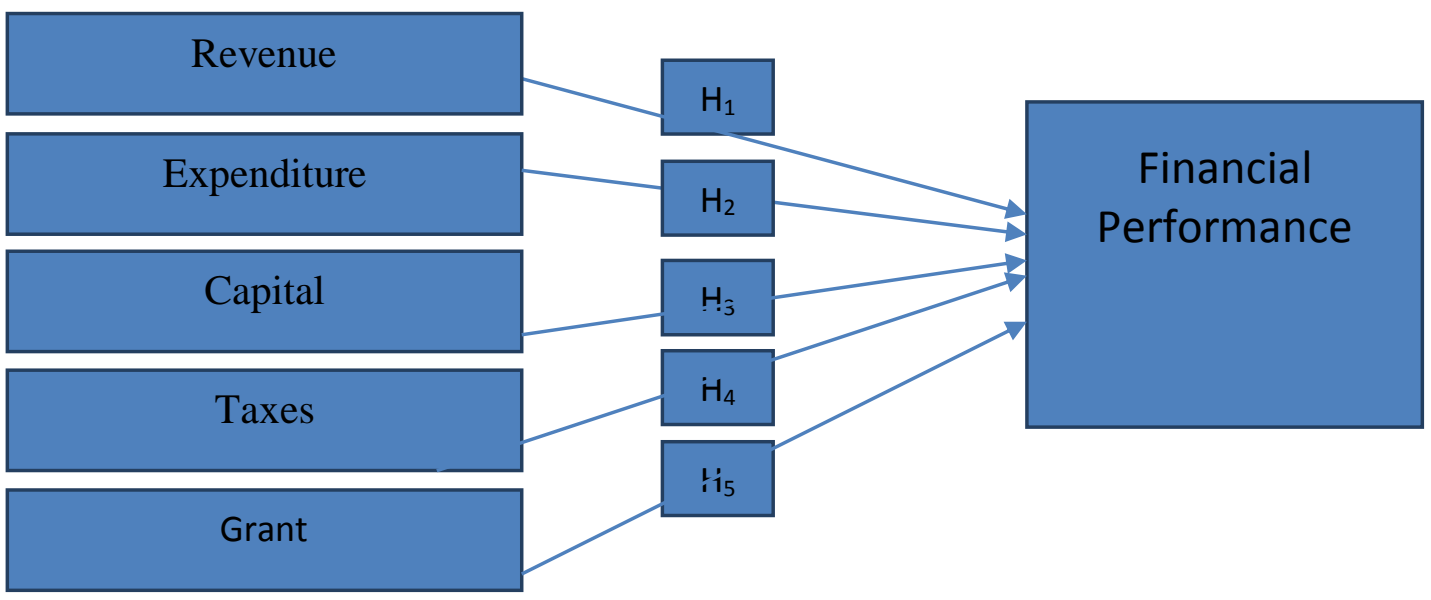

\subsection{Definition Operational}

Table 3.1: Measurement of Variables

\begin{tabular}{|c|c|c|}
\hline VARIABEL & INDICATOR & Measurement \\
\hline \multicolumn{3}{|c|}{ Dependent variable according to the Ministry of Home Affairs N.6690.900.327 of 1996} \\
\hline Effectiveness & $\frac{\text { Realization of Local Revenue }}{\text { Target of local revenue }}$ & \multirow{2}{*}{$\begin{array}{l}\leq 60: \text { Very not } \\
60-80: \text { Not } \\
80-100: \text { Efe,Efi } \\
>100: \text { Very }\end{array}$} \\
\hline Efficiency & $\frac{\text { Cost of Earning Local Revenues }}{\text { Realization of Local Revenue Receipts }}$ & \\
\hline Independence & $\frac{\text { Regional Original Income }}{\text { Central Assistance }+ \text { Loans }}$ & $\begin{array}{l}25-50: \text { Very Not } \\
50-75: \text { Not } \\
75-100: \text { Independe } \\
>100: \text { Very }\end{array}$ \\
\hline \multicolumn{3}{|c|}{ Independent Variable } \\
\hline Revenue & Accumulation Local Revenue in 1 year & Interval \\
\hline
\end{tabular}


Darussalam Province"

\begin{tabular}{|l|l|l|}
\hline Expenditure & Accumulation Local Expenditure in 1 year & Interval \\
\hline Capital & $\begin{array}{l}\text { Amount of equity presented in the regional } \\
\text { financial lap }\end{array}$ & Interval \\
\hline Taxs & The amount of tax received by the region & Interval \\
\hline Grant & Number of Donations received by the region & Interval \\
\hline
\end{tabular}

Type of research is inferential research by collecting research data in the form of Acehnese provincial government financial reports during the period 2009 - 2018 then processing it with the help of SPSS 13 for Windows with Bivariate Pearson Correlation analysis (Karl Pearson 1857-1936) with 3 basic decision making namely: (1) Based on the significance value of Sig. 2-tailed with significance $<5 \%$, (2) Based on r-count $>$ r-table of product moment, the value of $\mathrm{r}$ varies in the range -1 to +1 , the value of $\mathrm{r}$ approaching -1 or +1 means the two variables have a relationship strong, if close to 0 means weak. (3) Based on asterisks * SPSS:

The closeness intervals of the relationship are as follows (1) 0.00 to 0.20 : no correlation, (2) 0.21 to 0.40 : weak correlation. (3) 0.41 to 0.60 : moderate correlation, (4) 0.61 to 0.80 : strong correlation, (5) 0.81 to 1 : very strong correlation.

Chart 4.1 Histogram

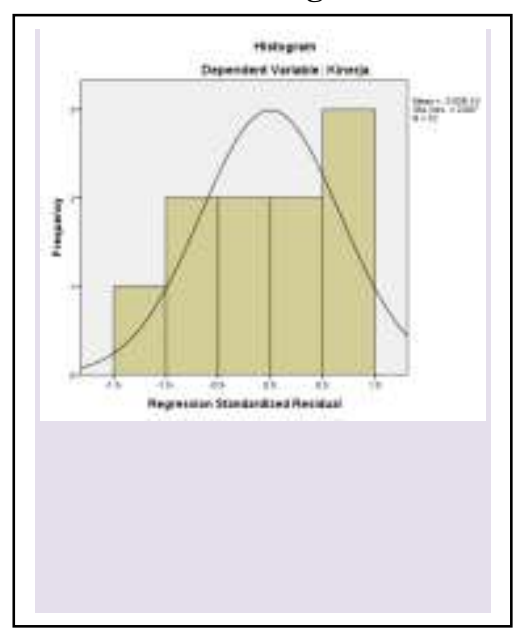

Chart 4.2 Normal P-Plot

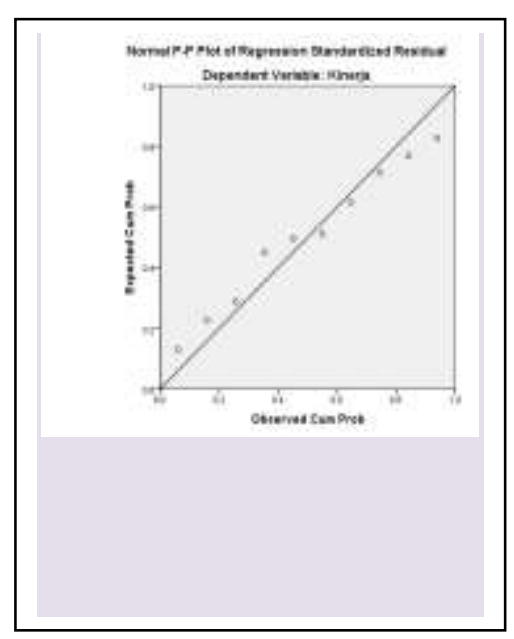

Table 4.2: K-S Test

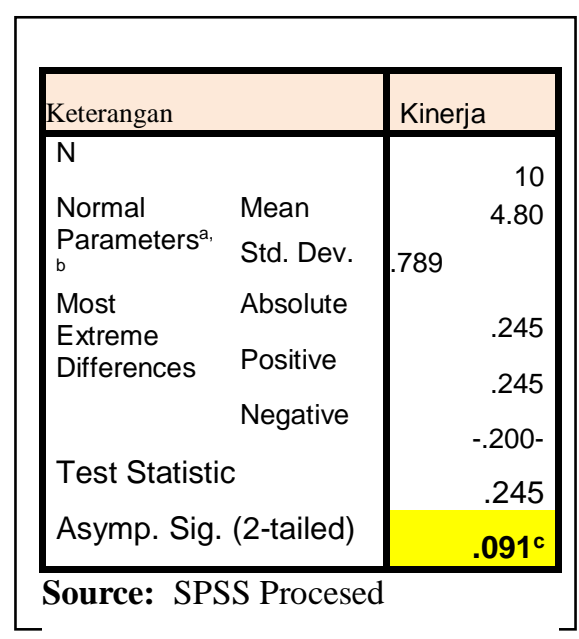

From the Chart table 1.1 above, the histogram forms a normal curve, then the residual is declared normal and the normality assumption is fulfilled. In graph 1.2: Normal PPlot above shows clearly that the plots follow a straight line plot, then the assumption of normality is fulfilled.

In the K-S test the data is said to be normally distributed if the significance level indicates a value greater than 0.05 . Whereas if the significance level is below 0.05 then the data are not normally distributed. Table 1.2 shows that the normality test for K-S has a normal distribution value. This is indicated by the K-S value of 0.245 with a significance of
The independent variables studied are revenue, expenditure, capital, grand, tax, and the dependent variable is the performance of government which is formed from three ratios of levels of efficiency, effectiveness and independence. In shaping performance variables, the three ratios were given an ordinal scala coding of each ratio without changing the measurement criteria of the Ministry of Home Affairs N.6690.900.327 in 1996.

\section{RESEARCH AND DISCUSSION}

\subsection{Normative Test}

There are two ways to detect whether a variable is normally distributed or not, namely by graphical analysis and statistical analysis. Graph analysis in this study uses the Histogram test and the P-P plot test, while the statistical analysis uses the Kolmogorov-Simornov (K-S) test. 
Table 4.3 Multicolliniearity Test

\begin{tabular}{|ll|l|l|}
\hline \multirow{2}{*}{\multicolumn{2}{|l|}{ Model }} & \multicolumn{2}{|l|}{ Collinearity Statistics } \\
\cline { 2 - 4 } & Tolerance & VIF \\
\hline 1 & (Constant) & \\
& Revenue & .004 & 266.936 \\
& Expenditure & .138 & 7.257 \\
& Capital & .228 & 4.394 \\
& Grand & .078 & 12.880 \\
& Taxs & .005 & 213.287 \\
\hline
\end{tabular}

Source: SPSS processed

Multicollinearity occurs when the VIF value (Variant Inflamation Factor> 5 (Mont Gomery, 2016), and Tolerance $<1$ (Gujarati, 2003), in table 1.3 above shows that the VIF value is above 5 and the tolerance value is also less than 1 so it can be concluded that none Multicollinearity or independent variables are not related systematically to each other.
Graph 4.2 Scaterplot Heteroskedatisidas Test

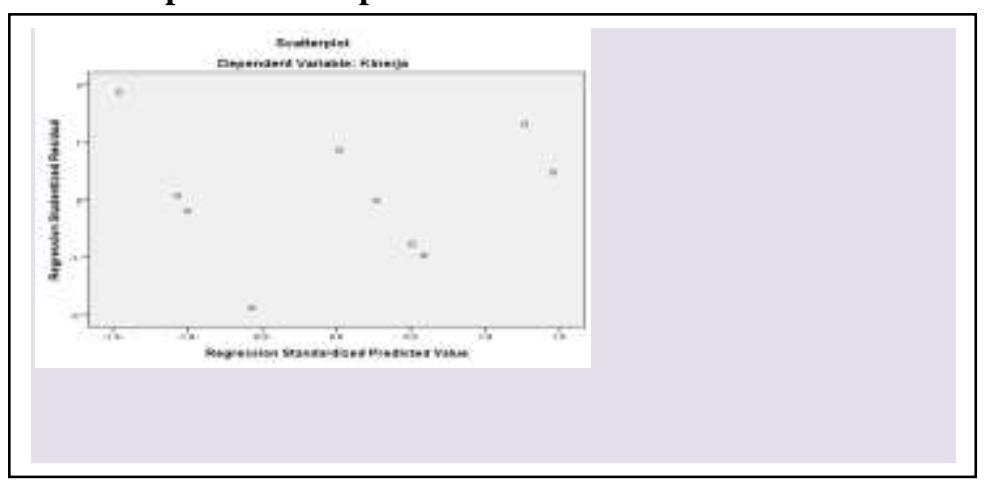

Table 4.4: Determination Coefficient Test (R2)

\begin{tabular}{|c|c|c|c|c|}
\hline Model & R & R Square & R Square Change & Sig. F Change \\
\hline 1 & $.961^{\mathrm{a}}$ & $\mathbf{. 9 2 3}$ & .923 & .024 \\
\hline
\end{tabular}

a. Predictors: (Constant), Taxs, Grand, Capital, Expenditure, Revenue

b. Dependent Variable: Kinerja

From table 1.4 above, it shows that the $\mathrm{R}$ square value is 0.923 which means that the revenue, expenditure, capital, grand and tax variables contribute to the contribution of the
In the Scatplot graph of the heteroscedasticidas 1.4 test above, it is seen that the distribution of points does not form a certain pattern, so it can be concluded that the regression model for the dependent variable does not occur heteroscedasticidas, so the regression model used is valid.

\subsection{Pearson Correlation Test}

\section{Table 4.5 Korelasi Pearson Test}

\begin{tabular}{|ll|c|c|c|c|c|c|}
\hline Information & & Revenue & Expenditure & Capital & Grand & Taxs & Kinerja \\
\hline Revenue & Pearson Correlation & 1 & $.841^{* *}$ & $-.123-$ & .140 & $.975^{* *}$ & $.912^{* *}$ \\
& Sig. (2-tailed) & & .002 & .735 & .701 & .000 & .000 \\
& $\mathrm{~N}$ & 10 & 10 & 10 & 10 & 10 & 10 \\
\hline \multirow{2}{*}{ Expenditure } & Pearson Correlation & $.841^{* *}$ & 1 & .138 & .003 & $.845^{* *}$ & $.816^{* *}$ \\
& Sig. (2-tailed) & .002 & & .703 & .993 & .002 & .004 \\
& $\mathrm{~N}$ & 10 & 10 & 10 & 10 & 10 & 10 \\
\hline Capital & Pearson Correlation & $-.123-$ & .138 & 1 & .238 & $-.090-$ & .142 \\
& Sig. (2-tailed) & .735 & .703 & & .507 & .805 & .696 \\
& $\mathrm{~N}$ & 10 & 10 & 10 & 10 & 10 & 10 \\
\hline Grand & Pearson Correlation & .140 & .003 & .238 & 1 & $-.051-$ & .137 \\
& Sig. (2-tailed) & .701 & .993 & .507 & & .888 & .707 \\
& $\mathrm{~N}$ & 10 & 10 & 10 & 10 & 10 & 10 \\
\hline Taxs & Pearson Correlation & $.975^{* *}$ & $.845^{* *}$ & $-.090-$ & $-.051-$ & 1 & $.903^{* *}$ \\
& Sig. (2-tailed) & .000 & .002 & .805 & .888 & & .000 \\
& $\mathrm{~N}$ & 10 & 10 & 10 & 10 & 10 & 10 \\
\hline Kinerja & Pearson Correlation & $.912^{* *}$ & $.816^{* *}$ & .142 & .137 & $.903^{* *}$ & 1 \\
& Sig. (2-tailed) & .000 & .004 & .696 & .707 & .000 & \\
& $\mathrm{~N}$ & 10 & 10 & 10 & 10 & 10 & 10 \\
\hline
\end{tabular}

**. Correlation is significant at the 0.01 level (2-tailed)

Sumber : Olahan Data SPSS. 
Based on the output table In table 1.5 above, it can be interpreted according to Pearson bivariate correlation analysis as follows: (1) Based on the significance value of Sg. (2-tailed). it can be seen that revenue, expenditure, and taxs have a significance value of 0,000 below 0.05 which means there is a significant correlation between the revenue, expenditure and tax variables with government performance. While the Grand and capital variables are significant above 0.05. (2) Based on the asterisk (*) SPSS, the variable relationships that have as many as 2 stars are revenue, expenditure, and taxs. It means that the relationship between revenue, expenditure and taxs with performance has a very high level of significance, namely $99 \%$ distrust level 0.01 (1\%). Relationships that have 1 star or with a level of mistrust of $5 \%$ (0.05) were not found. (3) Based on the Pearson correlation r-calculated value: (a) r-calculated revenue with performance is $0.912>$ r-table 0.632 (product moment table with $\mathrm{n}$ research 10 and sig.5\%). (b) $\mathrm{r}$-count expenditure with performance is $0.816>$ r-table 0.632 . (c) $r$ calculate taxs with performance is $0.903>\mathrm{r}$-table 0.632 . (d) grand r-count with performance is $0.13<$ r-table 0.632 . (e) $r$ calculate capital with performance is $0.14<$ r-table 0.632 .

The three variables, revenue, expenditure, and taxs, have rcalculated values all above the r-table, so it can be concluded that there is a relationship or chorealization between revenue, expenditure, and taxs and performance. If you look further into the degree of the relationship between the three variables, it can be seen that the magnitude of the r-count of all three> 0.81 , this means that the three variables have a very close relationship with the performance of the Aceh Darussalam provincial government.

As for the value of the grand r-count and capital for the $<r-$ table performance, it can be said that the grand and capital are very weak at all affecting the performance of the Aceh government.

\subsection{Hypothesis Test Results 4.3.1 Hypothesis $1\left(\mathrm{H}_{1}\right)$}

There is a close relationship between revenue and local government financial performance, this first hypothesis is accepted, this is shown in table 1.5 above in the Pearsonn bivariate correlation test with a significance level of 0,000 $<$ from 0.05 even 0.01 with an asterisk $(* *)$ two. The results of r-count of $0.912>$ r-table of 0.63 , the value of r-count above 0.81 shows that the relationship between revenue and performance is very close. This first hypothesis proves that the theory created by Mahmudi, McGowen, Jones and Walker all of which states that revenue has an influence on the ability of governments to produce proven financial performance.

Revenue or regional government revenue is used as a source of financing for regional development. According to Government Accounting standards, this regional income comes from PAD (regional original income) and transfer income from the central government. The revenue received by the Aceh regional government must be in the form of Regional Original Revenue (PAD) consisting of Aceh tax revenue, Aceh retribution revenue, income from managing Aceh's wealth and other legitimate Aceh original revenue. In this research the revenue studied is PAD (Regional Original Revenue) on the grounds that PAD is income that is truly based on the ability of local governments so that it can give an idea of the strength and ability of local governments in providing funds for regional development.

Revenue has a very strong influence relationship with the financial performance of the Aceh provincial government and this relationship is a positive relationship meaning that any strong increase in revenue will cause an increase in the financial performance of the Aceh provincial government, or the higher amount of revenue obtained by the Aceh regional government the greater the available funds for regional development so that the Aceh regional government is able to provide services to the people of Aceh better.

The increase in the amount of revenue is also followed by an increase in the financial performance of the local government also means that revenue revenue is also closely related to the improvement of the financial performance capabilities of the Aceh regional government. A large amount of revenue allows the Aceh regional government to carry out the work program of the local government more freely so that it is able to provide services quality to the community.

The higher revenue obtained by the Aceh regional government and the higher performance will provide strength in financial problems (monetary) this can overcome financial difficulties in terms of infrastructure funding for local government development, and also spending or other routine expenditure.

\subsubsection{Hypothesis $2\left(\mathrm{H}_{2}\right)$}

There is a close relationship between expenditure and financial performance of local governments, the second hypothesis is accepted, this is shown in table 1.5 above in the Pearsonn bivariate correlation test with a significance level of 0.004 <from 0.05 even 0.01 with an asterisk (**) two. The results of r-count of $0.912>$ r-table of 0.63 , the value of r-count above 0.81 shows that the relationship between expenditure and performance is very close. This second hypothesis proves that the theory developed by Halim, Damayanti, Mahmudi, and McGowen, which states that expenditure has an influence on the ability of the government to produce proven financial performance.

Expenditure is the amount of expenditure carried out by the Aceh regional government as routine expenditure, operational expenditure, and capital expenditure. High levels of government spending can reduce the amount of funds available to local governments and this can affect services that are set aside for the community, but if these local government spending is used for capital expenditure, development and other infrastructure then in the short term 


\section{Darussalam Province"}

it will indeed affect the financial structure or funds available but in the long run will be very beneficial for the community with the results of development and infrastructure which will also be earmarked and enjoyed by the community.

The high level of expenditure has a strong influence on the financial performance of the Aceh regional government, meaning that it also indicates an increase in the growth rate of development in the Aceh region carried out by the regional government to meet the infrastructure needs of facilities in service to the community.

\subsubsection{Hypothesis $3\left(\mathrm{H}_{3}\right)$}

There is a weak relationship between capital and local government financial performance, the third hypothesis is rejected, shown in table 1.5 above in the Pearsonn bivariate correlation test with a significance level of $0.969>$ of 0.05 and no asterisks there. The result of r-count is $0.142<\mathrm{r}$ table 0.63 . Although the relationship between capital and the financial performance of the Aceh government in this study is not significant, it does not mean there is no relationship between the two, but the amount of capital still has a relationship with the financial performance of the Aceh Darussalam regional government and the relationship is very weak, this is also shown by the results of the $r$ - count of 0.142 which is smaller than r-table and is at the interfal of less than 0.20 which is included in the very weak relationship group.

Capital or equity is the difference between assets (active) and liabilities owned by the Aceh regional government. Equity is used for capital to finance development. In this study, especially in 2009 until 2018 financial statement years, capital or equity did not closely affect the financial performance of the Aceh regional government, this could mean that the regional government was weak in the use of equity or absorption of capital budgets for development. This statement is in accordance with the DPRD Plenary Meeting (DPR) on Friday 05-25-2018 about LKPJ (Accountability Statement) The Governor of Aceh as the head of the Aceh government, which discussed the financial sector, the Aceh regional government has not been serious in collecting public money so the absorption is still lacking and causes economic growth of only $4.19 \%$ of the $8 \%$ targeted.

\subsubsection{Hypothesis $4\left(\mathrm{H}_{4}\right)$}

There is a weak relationship between grand and local government financial performance, the fourth hypothesis is rejected, shown in table 1.5 above in the Pearsonn bivariate correlation test with a significance level of $0.707>$ of 0.05 and no asterisks there. The results of r-count are $0.137<\mathrm{r}-$ table 0.63. Same with capital although the relationship between the grand and the financial performance of the Aceh government in this study is not significant, it does not mean there is no relationship between the two, but there is still a relationship with the financial performance of the
Aceh Darussalam regional government and the relationship is very weak, this is also shown by the results of -count of 0.142 which is at the interfal of less than 0.20 which belongs to the group of very weak relationships.

Grand is a donation or gift or gift from another party without any demands. In this study, the existence of the grand does not affect the financial performance of government closely or strongly, it can be explained that it is probable that there are contributions to the people of Aceh, especially after the tsunami, some developed countries directly provide assistance for the construction of houses, religious facilities and existing infrastructure such as the State of Turkey, is directly accepted by the local community. This is in line with the weak influence of capital on the financial performance of the Aceh regional government.

\subsubsection{Hypothesis $5\left(\mathrm{H}_{5}\right)$}

There is a close relationship between taxs and the financial performance of local governments, the sixth hypothesis is accepted, this is shown in table 1.5 above in the Pearsonn bivariate correlation test with a significance level of 0,000 $<$ from 0.05 even 0.01 with an asterisk (**) two. The results of r-count of $0.903>$ r-table of 0.63 , the value of r-count above 0.81 shows that the relationship between taxs and performance is very close. This fifth hypothesis proves that the theory created by McGowen and Anderson which states that taxs have an influence on the ability of governments to produce proven financial performance.

Taxs or taxes in this study are tax revenues from both the Aceh regional government and central and revenue-sharing taxes. High taxes can be a source of income for the local government and can be used as a source of funding for Aceh regional government operations in order to produce good services to the community and be able to increase the level of financial performance of the Aceh regional government as well.

\section{CONCLUSION AND RECOMMENDATION}

\subsection{Conclusion}

The research model using statistical analysis of Pearson Bivariate Correlation, has been valid and meets the assumptions of the classical test that is normality test, skedastisidas test, multicollinearity test and coefficient of determination test.

The results of a study of the Aceh Darusaalam government financial statements during 2009 - 2018 concerning the relationship of revenue, expenditure, capital, grand, and taxs to the financial performance of the Aceh government formed from the variables of efficiency, effectiveness, and independence show that: (1) The relationship between revenue and performance Aceh government finances are very closely related and positively linearly related. (2) The relationship between expenditure and the financial performance of the Aceh administration is very close and positively linear. (3) The relationship between capital and 
the financial performance of the Aceh government is very weak. (4) The grand relationship with the financial performance of the Aceh government is very weak. (5) The relationship of taxs with the financial performance of the Aceh administration is very close and positively linearly related.

\subsection{Recommendation}

Local Own Revenue or PAD is very closely related positively to financial performance, meaning that an increase in PAD will lead to an increase in the financial performance of the Aceh Province government, so it is recommended that this PAD is always increased, especially revenue from the Aceh natural resource management sector To increase economic growth according to the target of $8 \%$, it is recommended that the Aceh provincial government optimize the absorption of its financial budget, especially for capital expenditure, and the construction of infrastructure facilities for the community.

\section{REFERENCES}

1. Bendarkawi, Anass (2020). "Confusion and Amalgam: The Firm's Productivity and Related Concepts Performance, Effectiveness, Efficiency and Production". Accaunt and Financial Management Journal, 5(11), 2263-2268.

2. Cohen, Sandra, (2006). "Identifying the moderator factor of financial performance in Greek Municipal," Annuall Conference. $5^{\text {th }}$. HFAA. Thessaonica.

3. Godsey Maureen and Shulman A. Martha. (1981). "Financial indicators for local government". Public Budgeting and Finance 1(2) 5-19

4. Governmental Accounting Standards Board (GASB), (1994). "Objectives of financial reporting concepts statement no, Stamford," CT: GASB

5. Hery. (2015). “Analisis Laporan Keuangan, Pendekatan Rasio Keuangan.” Jakarta.CAPS (Center for Academic Publishing Service).

6. Halim, Abdul dan Damayanti. (2008). "Manajemen Keuangan Daerah: Seri Bunga Rampai”. Yogyakarta: BPFE

7. Ikatan Akuntan Indonesia. (2004). "Standar Akuntansi Keuangan." Jakarta: Salemba Empat, 2004.
8. Jones, Stewart and R., G., Walker. (2007). "Explanators of local Government Distress. ABACUS. 43(3) 396-418.

9. Mahmudi. (2007) "Analisis laporan keuangan Pemerintah Daerah”. Jogjakarta: UPP. STIM. YKPN.

10. SAK, (2008). "Pernyataan Standart Akuntansi Pemerintah. Pernyataan No. 1. Penyajian Laporan Keuangan”. Jakarta: Salemba Empat.

11. Plammer, E., Hutchison and Patton, T. (2007). “GSAB No. 34's Government financial reporting model: Evident on its information relevan". The Accounting Review. 82(1), 205-240.

12. Rahadjo, Wiharta. (2010). "PengaruhPosisi Keuangan Terhadap Kinerja Keuangan Pemerintah Daerah di Solo, Indonesia". Thesis: Jurusan Akuntansi, Pasca Sarjana UNS

13. Srinivasarao, Yadarvalli et.al. (2020). "Impact of Financial Antecedensts on Financial Performance of SMEs" Accaunt and Financial Management Journal, 5(10), 2250-2255.

14. Suyono, (2010). "Analisa Kinerja Keuangan Pemerintah Daerah di Indonesia, Solo”. Jurnal Akuntansi dan Bisnis, 10 (2), 1-10.

15. Scott, W.R. (2003)" Financial accounting theory". Toronto Canada: Prentice-Hall.

16. Subramanyam and John J Wild. (2014). "Analisis Laporan Keuangan”. Jakarta: Salemba Empat.

17. UU Nomor 25 Tahun 1999 dan telah direvisi melalui Undang Undang Nomor 33 Tahun 2004 tentang Perimbangan Keuangan Pemerintah Pusat dan Daerah, Departemen Dalam Negeri RI, Jakarta.

18. UU Nomor 17 Tahun 2003 Tentang Keuangan Negara. Departemen Dalam Negeri RI, Jakarta.

19. UU Nomor 1 dan 32 Tahun 2004 Tentang Perbendaharaan Negara. Departemen Dalam Negeri RI, Jakarta.

20. https://bpka.acehprov.go.id Laporan Keuangan Aceh Darussalam Tahun 2010 - 2018

21. Zahra, Milla Himmatuz dan Provita Wijayanti, (2019) "Antecedent financial performance of Baitul Mal wat Tamwil (BMT) : Study in BMT Binama Semarang" Journal of Islamic Accounting and Finance Research, 1 (1), 47-78 